Original Research Paper

\title{
Pemberdayaan Masyarakat Dalam Rehabilitasi Hutan dan Lahan Kritis di Wilayah Sekaroh Lombok Timur: Belajar Dari Pengalaman Masyarakat
}

\author{
Suwardji $^{1 *}$, Sri Tejowulan¹, Agil Al Idrus², Abdul Syukur², A. Raksun² dan Parman ${ }^{3}$ \\ ${ }^{1}$ Program Studi Ilmu Tanah Fakultas Pertanian Universitas Mataram Lombok Indonesia; \\ ${ }^{2}$ Program Studi Pendidikan Biologi, Fakultas Keguruan dan Ilmu Pendikan Universitas Mataram Lombok Indonesia \\ ${ }^{3}$ Fakultas Hukum Universitas Mataram, Mataram Lombok Indonesia
}

https://doi.org/10.29303/jpmpi.v3i2.950

Sitasi: Suwardji., Tejowulan, S., Muslim, B., Idrus, A. A., Syukur, A., Raksun, A \& Parman. (2021). Pemberdayaan Masyarakat Dalam Rehabilitasi Hutan dan Lahan Kritis di Wilayah Sekaroh Lombok Timur: Belajar Dari Pengalaman Masyarakat. Jurnal Pengabdian Magister Pendidikan IPA, 4(4)

\section{Article history}

Received: 15 September 2021

Revised: 20 September 2021

Accepted: 25 September 2021

*Corresponding Author:

Suwardji, Program Studi Ilmu

Tanah Fakultas Pertanian

Universitas Mataram Lombok

Indonesia; Email:

suwardji@unram.ac.id

\section{Pendahuluan}

$\mathrm{H}$ utan dan lahan merupakan sumberdaya alam penting tempat berbagai kehidupan bergantung. Tumbuhan, hewan dan manusia semuanya memanfaatkan sumberdaya hutan dan lahan serta ekosistimnya untuk memenuhi berbagai
Abstrak: Forests and land degradationn in the Sekaroh and Pemongkong Villages of East Lombok areas has reached a very severe level. Since the 1990 s the government has made various efforts to reforestation and rehabilitate forests and critical land in this area on a massive scale, but data showed that the success rate was still very low or far from expectations. The paper presented in this journal was our a two-years participatory study (2002-2004) that is still very relevant to the massive destruction of forests and land that occurred in NTB. The method used in this study was Participatory Rapid Appraisal (PRA) method which involves stakeholders involved in forest and land rehabilitation efforts. The results of the 2 year participatory study were able to encourage a ways to overcome the problems of forests and land degradation in the Village of Sekaroh and Pemongkong and Sekaroh vilages by packaging a development paradigm based on local potential both natural resources and human resources by emphasizing community learning (action learning) and community empowerment as development capital. The social capital paradigm developed through real learning is social capital that is based on 'togetherness', namely by trying to see the positive roles of social institutions to be played in the learning process in the management of forests and land degradation in Sekaroh and Pemongkong villages. The action learning process that has been carried out has succeeded in encouraging a collaboration between institutions such as religious institution, customary institutions, local government and the Working Group on Forest and Land Degradation as facilitators in the preparation of forest and critical land management plans for the short, medium and long term.

Keywords: Moral, Generasi Muda, Pernikahan Dini, Nilai-nilai Agama dan Budaya

kebutuhan hidup mereka. Sangat disayangkan, kondisi hutan dan lahan yang ada di Propinsi Nusa Tenggara Barat (NTB) telah banyak yang sudah mengalami degradasi sampai ke tingkat yang cukup parah sehingga tidak lagi dapat berfungsi dan dimanfaatkan secara berkelanjutan untuk meningkatkan kesejahteraan masyarakat yang tinggal disekitarnya. 
Di Desa Sekaroh dan Pemongkong Kecamatan Jerowaru Lombok Timur, kawasan hutan dan lahannya juga telah mengalami kerusakan yang sangat parah. Penebangan hutan, pengambil alihan lahan hutan, dan pemanfaatan lahan hutan untuk lahan pertanian telah menyebabkan terjadinya kerusakan hutan dan lahan sehingga menimbulkan dampak sosial-ekonomi, sosial-budaya dan lingkungan yang parah.

Menurut cerita para tetua adat dari Desa Sekaroh dan Pemongkong, diawal tahun 1970-an kawasan Sekaroh yang dikenal dengan Gawah Sekaroh-nya (Hutan Sekaroh) masih merupakan hutan yang sangat lebat dengan berbagai potensi keanekaragaman flora dan fauna daratnya. Manusia tidak banyak yang berani memasuk ke dalam Gawah Sekaroh kecuali para penggembala ternak sapi dan kerbau dari kecamatan lain baik dari Lombok Tengah dan Lombok Timur. Berbeda dengan keadaannya yang ada sekarang Gawah Sekaroh tidak lagi merupakan Gawah melainkan hanya berupa status kawasan hutan lindung yang banyak dimanfaatkan untuk perladangan liar dan penggembalaan liar. Hanya sebagian kecil saja $( \pm$ $400 \mathrm{Ha}$ ) dari kawasan hutan yang ada tersebut yang sekarang ini masih berbentuk hutan dengan kondisinya yang sangat minim.

Pemerintah melalui berbagai dinas dan instansi yang terkait sejak tahun 1990 telah melakukan berbagai upaya reboisasi dan rehabilitasi hutan dan lahan dengan menanam ratusan ribu bahkan jutaan bibit tanaman pohon ke wilayah ini. Namun kenyataan menunjukkan bahwa kegiatan ini tidak mampu meningkatkan kondisi hutan dan lahan yang telah mengalami kerusakan bahkan dapat dikatakan gagal. Jumlah lahan kritis dan hutan yang rusak di Sekaroh dan Pemongkong terus meningkat dan sulit untuk dikenndalikan.

Hambatan utama pengelolaan hutan dan lahan kritis di wilayah Sekaroh dan Pemongkong terletak pada kondisi biofisik lahan dan permasalahan sosial ekonomi dan budaya masyarakatnya. Kawasan Sekaroh dan Pemongkong yang luasnya kurang lebih 12.000 hektar tersebut terdapat di atas daratan hasil pengangkatan atau up-lifting landform muka air laut (Tarningsih et al, 2010). Dengan batuan induk kapur hasil deposit biota laut tersebut dan kondisi iklimnya yang sangat kering yaitu E4 (Oldeman et al, 1980) dengan dua hingga tiga bulan basah setiap tahunnya, dan sangat eratik sehingga menyebabkan produktivitas tanaman pangan lahan kering sangat rendah apalagi akibat kondisi biofisik wilayah Sekaoroh dan Pemongkong ini yang kering dan tingkat kesuburannya rendah. Hal inilah yang menjadi penyebab utama tingginya angka kemiskinan dan berakibat secara tidak langsung terhadap kerusakan hutan dan lahan jika tidak dikelola dengan baik dan benar (Suwardji et al 2019).

Keadaan ini diperparah oleh kondisi sosial ekonomi budaya masyarakat yang kurang menguntungkan, seperti jumlah penduduk yang terus bertambah, kemiskinan yang tidak kunjung dapat diatasi, tingkat pendidikan yang rendah, dan kelangkaan alternatif lapangan kerja diluar bidang pertanian dan kehutanan. Selain itu kerusakan hutan dan lahan juga disebabkan oleh kurangnya pemahaman dan kepedulian masyarakat dan pemerintah terhadap pentingnya pelestarian lingkungan.

Apabila keadaan seperti ini tidak mendapatkan perhatian yang serius, jumlah hutan dan lahan kritis akan terus bertambah dan kedepan keadaan ini akan dapat mengancam keberlanjutan pembangunan dan masa depan kehidupan masyarakat di kawasan tersebut. Oleh sebab itu, upaya pelestarian hutan dan lahan kritis harus terus diperhatikan dan didukung oleh semua pihak.

Menyadari adanya permasalahan yang kompleks dalam pengelolaan hutan dan lahan kritis di Desa Sekaroh dan Pemongkong, Kelompok Kerja (POKJA) Provinsi Hutan dan Lahan bekerjasama dengan BAPEDALDA Provinsi NTB dan BRISK PROJECT Aus AID Denpasar pada tahun 2002-2004 mencoba menggali akar permasalahan penyebab terjadinya kerusakan hutan dan lahan serta mencoba mencari alternatif solusi pemecahan untuk mengembalikan kondisi hutan dan lahan kritis ke keadaan yang lebih baik dan sehat. Kerja partisipatif POKJA Hutan dan Lahan Provinsi NTB mendapat dukungan dari Aus-AID Project Australia yang menangani masalah hutan dan lahan kritis.

Pengalaman studi partisipatif dalam upaya pengelolaan hutan dan lahan kritis selama dua tahun (2002-2004) di wilayah Sekaroh dan Pemongkong ditulis dalam paper ini sebagai pengalaman yang dapat dikembangkan dan dipelajari lebih lanjut oleh generasi muda melenial dan pemangku kepentingan yang lain sehingga ke depan mampu mengatasi berbagai permasalahan 
kerusakan hutan dan lahan di wilayah ini yang belum dapat diatasi sampai sekarang.

\section{Metode}

Metode yang digunakan dalam studi ini adalah metode participatory rapid appraisal (PRA), metode yang diyakini dapat membangun kebersamaan serta akses semua pemangku kepentingan(stekeholders) untuk memberikan kontribusi serta solusi baik secara langsung maupun tidak langsung terhadap permasalahanpermasalahan nyata yang ditemukan dalam pengelolaan hutan dan lahan kritis.

Penggunaan metode partisipatif dengan pendekatan pembelajaran nyata (action learning) bertujuan untuk mengubah pola pikir serta perilaku negatif menjadi positif semua pemangku kepentingan dalam pengelolaan hutan dan lahan kritis. Selain itu, kekuatan metode partisipatif tersebut dapat memberikan pemberdayaan bagi masyarakat yang dicirikan oleh : (1) timbulnya kesadaran, dimana mereka sadar atas haknya terhadap sumberdaya lingkungan di sekitar hutan dan lahan kritis serta sanggup menjalankan kewajiban dan tanggung-jawabnya untuk mengelola agar tercapai kualitas lingkungan hutan dan lahan kritis yang dituntutnya, (2) berdaya, yaitu mampu melakukan tuntutan untuk mendapatkan lingkungan hutan dan lahan yang lestari, (3) mandiri, yaitu mampu dengan inisiatif lokal untuk mengatasi masalah-masalah lingkungan hutan dan lahan, dan (4) mampu memperjuangkan aspirasi untuk tuntutan agar lingkungan hutan dan lahan menjadi andalan kehidupan bukan saja bagi generasi sekarang tetapi juga generasi yang akan datang. Sepuluh orang dari generasi muda dan tokoh masyarakat dari Desa Sekaroh dan Pemongkong telah dilibatkan aktif dalam Tim Pokja Hutan dan Lahan Provinsi dalam studi ini. Kegiatan yang diawali dengan kegiatan pelatihan metode PRA dengan mempelajari dasar dasar teknik PRA tersebut adalah : (1) alur sejarah, (2) klasifikasi kesejahteraan, (3) kecenderungan dan perubahan, (4) diagram kelembagaan, (5) pengambilan keputusan, (6) pemetaan sosial dan sumber daya, (7) matrik rangking, (8) kalender musim, (9) transek, (10) sketsa kebun, (11) alur masukan dan pengeluaran, (12) analisis mata pencaharian, dan (13) wawancara terstruktur
(WST) (Konsorsium Dataran Tinggi Nusa Tenggara, 2000).

Pada pelaksanaan kegiatan Pokja Hutan dan Lahan prinsip-prinsip participatory tetap dilaksanakan. Namun demikian mengingat kondisi sosial budaya serta pendidikan masyarakat yang masih rendah disisipkan atau dikombinasikan dengan beberapa metode lainnya seperti : ceramah, curah pendapat (brainstorming), focus group discussion (FGD), simulasi, peragaan (demonstration), bermain peran (role playing), dan kerja lapangan. Pelaksanaan kegiatan dilakukan malalui tahapan-tahapan sebagai berikut:(a) Kegiatan sosialisasi, yaitu: (1) memberikan informasi kepada masyarakat tentang keberlanjutan program pelaksanaan yang telah disusun bersama masyarakat, (2) mengkondisikan masyarakat agar memiliki kesiapan baik waktu dan tenaga untuk melaksanakan program. (b) Dalam pelaksanaan kegiatan sosialisasi ini Pokja membentuk tim kecil yang bertugas untuk melakukan pertemuan dengan kelompok masyarakat dalam membuat kesepakatan bersama pada proses pelaksanaan kegiatan, yaitu tentang: (1). Waktu dan tempat pelaksanaan kegiatan pelatihan.(2) Tehnis pengaturan logistik dan akomodasi selama kegiatan pelatihan.(3). Keamanan selama kegiatan pelatihan.

Tahapan ini dilaksanakan untuk memberikan peran pada masyarakat dalam proses pembelajaran untuk mengorganisasikan kegiatan sehingga tumbuh rasa tanggung jawab terhadap proses kegiatan dan hasil yang dicapai. (1) Membuat Kontrak Kerja dengan masyarakat, pada tahap ini Pokja I memfasilitasi proses pelaksanaan kegiatan untuk membuat kesepakatan pelaksanaan. Tahap kedua ini dilaksanakan untuk meningkatkan kemampuan kelompok dalam menyusun dan menetapkan bentuk kontrak kerja sebagai pedoman pelaksanaan kegiatan (2) Pelatihan di Kelas dan Lapangan, tahapan ini merupakan kelanjutan dari tahap 1 dan 2. Pada tahap ini fasilitator menyiapkan materi pelatihan serta ruang diskusi bagi masyarakat tentang : (a) Penyusunan rencana kerja bersama secara partisipatif untuk pengelolaan hutan dan lahan kritis (b) Teknik pelaksanaan kegiatan berdasarkan rencana kerja partisipatif untuk pengelolaan hutan dan lahan kritis.(3) Teknik perumusan hasil diskusi.Tahapan ini bertujuan untuk melatih masyarakat secara langsung untuk mengenal permasalahan riil atau kondisi nyata yang dialami masyarakat berdasarkan prioritas untuk 
diorganisasikan ke dalam program serta upaya atau solusi yang diperlukan untuk penyelesaiannya. (4). Pleno, tahap pleno ini dilakukan untuk mempresentasikan hasil-hasil yang telah didapat selama periode kegiatan tertentu di tingkat gubuk dan kemudian ditanggapi atau dikomentari oleh peserta pleno yang lainnya. Pleno dihadiri oleh semua perwakilan gubuk, wakil pemerintah, Toga dan Toma, dan pemangku kepentingan lainnya serta seluruh anggota Pokja Hutan dan Lahan. Tujuan pleno adalah: (1) untuk menyempurnakan dan melihat kembali hasil-hasil yang telah didapat di tingkat gubuk sebelumnya, (2) untuk melatih masyarakat mengungkapkan dan mempresentasikan hasil di depan forum, dan (3) memberikan kesempatan kepada peserta lainnya untuk berpendapat dan menyempurnakan hasil yang dipresentasikan.(5). Refleksi, tahap refleksi ini adalah merupakan bagian yang sangat penting karena refleksi dapat memberikan gambaran tentang kelemahan-kelemahan yang terjadi untuk diperbaiki pada proses berikutnya. Kegiatan refleksi dilakukan baik bersama masyarakat maupun antar anggota Pokja. (5). Monitoring dan Evaluasi, tahap ini diperlukan untuk melihat apakah proses yang telah dilaksanakan sudah dapat membuat masyarakat menjadi kritis dalam menganalisis permasalahan yang ada serta untuk melihat apakah proses yang sudah dilakukan sudah baik atau masih banyak kelemahan-kelemahannya. Hasil dari tahap ini akan dijadikan dasar untuk menyusun program berikutnya.

\section{Hasil dan Pembahasan}

Hasil pembelajaran dengan metode partisipatif (PRA) selama dua tahun (2002-204) bersama masyarakat Sekaroh dan Pemongkong dapat dapat ditemukan: (A) Beberapa masalah penting yang dibahas berikut ini: (1) tuntutan hidup yang semakin berat, (2) konflik pengelolaan sumberdaya alam, (3) praktek-praktek pertanian yang tidak bijak, (4) sistim penggembalaan liar yang turun temurun, dan (5) permasalahan kepemilikan tanah. Sedangkan hasil pelaksanaan (B) Pembelajaran nyata bersama masyarakat (action learning) di Sekaroh dan Pemongkong selama dua tahun adalah: (1) terbentuknya masyarakat penghubung "Penjuluk", terbentuknya kelompok simpan pinjam, terbentuknya kader pengerak untuk pengelola hutan dan lahan kritis (4) meningkatnya kesadaran pengelolaan hutan dan lahan kritis, (6) meningkatnya kemampuan masyarakat Montong Bile yang terampil memelihara kambing dan (7) meningkatnya kemampuan masyarakat Erot yang terampil dalam berkebun srikaya dan menanam bakau

\section{A. Beberapa Permasalahan Yang Ditemukan \\ 1. Tuntutan Hidup Masyarakat yang Semakin Berat}

Kenyataan menunjukkan bahwa kebijakan pembangunan yang berlangsung selama ini semakin lama menyebabkan kehidupan masyarakat semakin sulit. Usahatani yang dilakukan oleh masyarakat sebelumnya mampu mencukupi kebutuhan keluarga, pada saat ini tidak dapat lagi menjamin pemenuhan kebutuhan tersebut. Hal ini terkait erat dengan kondisi krisis ekonomi nasional yang terjadi sejak pertengahan tahun 1997 dan masih dirasakan dampaknya hingga saat ini. Sulitnya usaha alternatif di luar bidang pertanian yang dapat dilakukan oleh masyarakat dengan kemampuan yang ada pada saat ini telah mendorong mereka mengambil jalan pintas melakukan pekerjaan yang mudah dan cepat menghasilkan yaitu dengan melakukan penebangan kayu untuk mendapatkan uang tunai (cash money). Untuk mengatasi permasalahan tersebut bukanlah persoalan yang mudah. Dari proses pembelajaran dengan masyarakat Sekkaroh dan Pemongkong, menunjukkan masih adanya banyak usaha alternatif dalam pengembangan sumberdaya lokal yang dapat digunakan untuk mengatasi masalah kemiskinan di wilayah ini. Salah satu upaya yang dapat dilakukan adalah mengembangkan sistim pertanian terpadu(integrated dryland farming) berbasis tanaman pohon - tanaman pangan - rumput dan ternak. Hasil riset lapangan tentang agroforestry yang di inisiasi oleh Almarhum TGH. Sibawai yang dikokumentasikan oleh Suwardji et al (2019) telah membuktikan pengembangan agroforestry mampu memperbaiki kualitas lahan dan sekaligus mampu meningkatkan kesejahteraan masyarakat. Jika hal ini dapat diimplementasikan, diperkirakan dapat memotong siklus kemiskinan yang menjadi 
penyebab utama kerusakan hutan dan lahan di daerah ini. Upaya lain untuk meningkatkan kesejahteraan masyarakat dapat dilakukan melalui pengeloaan pesisir dan laut yang ada disekitar Desa Pemongkong. Aksi pembelajaran masyarakat juga telah dilakukan oleh Almarhum TGH Sibawai telah membuktikan hal ini melalui ajarannya Eco Movement yang telah melakukan rehabilitasi lahan mangrove lahan pantai Pemongkong lebih dari 6 Km (Suwardji et al, 2019). Kembali pada permasalahan inti yang perlu digarap secara serius adalah bagaimana komitmen bersama dalam memberdayakan masyarakat (community empowerment) secara luas. Masyarakat Pemongkong yang dulu setelah berladang tidak bisa memperoleh pendapatan lain, dengan adanya mangrove hasil rehabilitasi lahan pantai bersama masyrakat yang di pelopori TGH Sibawai sekarang setelah ke selesai bekerja di ladangnya, dapat pergi ke hutan mangrove dan mencari kepiting yang dalam jangka waktu 2-3 jam saja dapat memperoleh 3-4 kg dengan harga Rp.50.000/kg. Peningkatan pendapatan masyarakat telah dirasakan saat ini dan mereka mulai sadar pentingnya menjaga dan pemperbaiki kualitas hutan dan lahan yang terdegradasi.

\section{Konflik Pengelolaan Sumberdaya Alam}

Konflik pengelolaan sumberdaya alam telah ada sejak lama. Namun di era orde-baru, konflik-konflik pengelolaan sumberdaya alam ini tidak mengemuka karena struktur politik yang cenderung represif. Adanya perubahan struktur politik di era reformasi dan pelaksanaan otonomi daerah sekarang ini, telah menyebabkan keterbukaan di berbagai sektor yang luas, termasuk keterbukaan informasi, sehingga konflik-konflik pengelolaan sumberdaya alam tersebut sekarang bermunculan di mana-mana.

Perubahan kebijakan pemerintah di era otonomi daerah dan keterbukaan ini membawa dampak luas tentang pengertian pengelolaan sumberdaya alam yang selama ini salah. Pengelolaan hutanpun tidak luput dari berbagai sengketa dan untuk mengatasinya perlu mengikutsertakan semua pemangku kepentingan dan pihak yang bersengketa.
Pengelolaan hutan dan lahan kritis di wilayah Sekaroh dan Pemongkong tidak terlepas dari berbagai konflik kepentingan. Antara orang yang tinggal di Sekaroh dan Pemongkong dan orang yang tinggal di luar Sekaroh dan Pemongkong. Antara orang yang berkepentingan untuk memperoleh sumberdaya hutan dan lahan serta orang yang berkepentingan untuk memperoleh lahan usaha. Antara peladang dan penggembala dan bahkan pihak-pihak lain seperti investor yang ingin menanamkan modalnya di wilayah itu juga melakukan berbagai usaha seperti pembakaran kapur, pengelolaan pantai dan lain sebagainya. Salah satu contoh yang menarik hasil belajar bersama yang dilakukan Pokja Hutan dan Lahan bersama masyarakat adalah diperolehnya kesepakatan di tiga dusun untuk tidak menjual tanahnya kepada orang luar jika tanahnya tersebut tidak dikelola dengan baik.

Belajar bersama dengan masyarakat di sekitar hutan di wilayah ini menunjukkan betapa banyaknya konflik pengelolaan sumberdaya alam terutama yang terkait dengan hutan dan lahan. Diantara pemicu konflik tersebut adalah adanya kebijakan pemerintah yang kurang memihak kepada masyarakat, aktivitas penebangan hutan oleh orang-orang dari luar, penggembalaan liar, oknum pemerintah yang tidak bersih, dan lain sebagainya. Untuk mengatasi hal tersebut di atas diperlukan fasilitasi yang kuat untuk dapat mengajak berbagai pihak yang bersengketa duduk bersama dalam merancang kepentingan bersama dalam pengelolaan sumberdaya hutan dan lahan di daerah ini. Hanya dengan jalan itulah berbagai konflik kepentingan akan dapat dicari solusi penyelesaian yang dapat disepakati oleh pihak-pihak yang bersengketa.

\section{Praktek-praktek pertanian yang tidak berkelanjutan}

Tanpa disadari masyarakat di sekitar hutan masih melakukan praktek-praktek pertanian yang justru merusak lingkungan. Pemerintah telah melarang praktek pembakaran ladang pada awal musim hujan. Namun kenyataan menunjukkan bahwa masyarakat masih mempraktekkan pembakaran ladang sebelum memulai musim 
tanam karena cara ini yang mereka anggap mudah dan murah. Disamping itu, pembakaran padang rumput dan semak oleh penggembala masih sering dilakukan, yang sering menyebabkan terjadinya kebakaran hutan. Jika ditanyakan kepada masyarakat Sekaroh dan Pemongkong siapa yang salah dengan praktekpraktek pertanian yang tidak berkelanjutan seperti ini akan sulit dicari jawabannya.

Beberapa praktek pertanian dan penggembalaan di daerah ini tampak menjadi penyebab utama sering terjadinya kebakaran hutan dan matinya tanaman-tanaman muda yang baru ditanam. Berbagai upaya yang telah dilakukan belum dapat mengatasi permasalahan ini. Dari belajar selama dua tahun dengan masyarakat di desa Sekaroh dan Pemongkong memberikan petunjuk bahwa upaya meningkatkan keperdulian bersama untuk memperhatikan pembakaran rumput untuk persiapan tanaman dan pembakaran rumput dalam pengelolaan alang-alang merupakan cara yang paling memungkinkan untuk mengurangi dan menghindari terjadinya kebakaran hutan yang tidak terkendali.

Menggalang kesadaran bersama untuk memecahkan permasalahan ini, melalui penguatan kelembagaan adat yang sudah ada di masyarakat, mungkin merupakan cara yang paling efektif untuk mengurangi terjadinya kebakaran hutan. Hal ini sudah dibuktikan oleh masyarakat di Dusun Erot dan Montong Bile Desa Pemongkong yang menerapkan kesepakatan adat bersama untuk meminimalkan terjadinya kebakaran hutan dan ladang. Namun untuk menghilangkan sama sekali praktek-praktek pertanian yang kurang bijak seperti yang dijelaskan di atas sangatlah sulit dilakukan, kecuali ada alternatif lain yang mudah dan murah serta terjangkau oleh masyarakat. Pertimbangan biaya masih menjadi pertimbangan utama dalam pengembangan praktek-praktek pertanian yang dilakukan di Desa Pemongkong dan Sekaroh.

\section{Sistim pengembalaan yang turun temurun}

Wilayah hutan Sekaroh menyimpan potensi sumber pakan ternak yang besar. Hal ini telah dibuktikan oleh Suryanigsun dan Suwardji (2009) dalam penelitiannya tentang potensi tumbuhan liar di wilayah Sekaroh sebagai pakan ternak. Menurut penuturan orang-orang tua di Desa Sekaroh dan Pemongkong, sudah sejak ratusan tahun yang lalu wilayah ini merupakan padang penggembalaan sapi dan kerbau bagi masyarakat dari Lombok Tengah (Pujut, Mujur, Ganti) dan Lombok Timur (Rensing, Sakra, Keruak, Jerowaru). Pada saat musim hujan dimana tidak ada lagi tempat untuk menggembalan ternak mereka di tempattempat tersebut di atas (karena ditanami padi), para pemilik ternak melalui sistim penggembalan yang terampil dan professional menggembalakan ternaknya ke Wilayah Hutan Sekaroh selama berbulan-bulan. Ribuan sampai puluhan ribu ternak datang ke wilayah ini setiap tahunnya (Tejowulan et al, 2004). Bahkan para penggembala telah mengklaim wilayah penggembalaannya serta mempunyai tempat-tempat khusus untuk menyiapkan persediaan air minum untuk ternaknya serta tempat tinggal sementara para penngembalanya ketika melakukan pengembalaan di Desa Sekaroh dan Pemongkong.

Permasalahan yang sering timbul dalam pola penggembalaan liar seperti ini adalah dalam perjalanan menuju dan kembali/pulang dari wilayah Sekaroh. Pada perjalanan tersebut hewan-hewan sering merusak tanaman masyarakat disepanjang perjalanan. Sebagai akibatnya konflik antara penggembala dan masyarakat sering terjadi karena kerusakan tanaman yang disebabkan oleh penggembalaan tersebut. Dari hasil belajar dengan masyarakat di Desa Sekaroh dan Pemongkong dapat diketahui bahwa dengan menerapkan sistim denda melalui sistem awig awig yang dikembangkan masyarakat bagi ternak yang merusak tanaman mereka ternyata cukup efektif untuk mengendalikan kerusakan tanaman yang disebabkan oleh penggembalaan ternak. Namun dalam prakteknya sering sulit menetapkan tingkatan denda yang sebanding dengan tingkat kerusakan tanaman yang diakibatkan penggembalaan yang tidak terkendali.

Selain itu, permasalahan yang pelik juga muncul ketika pemerintah berupaya untuk melakukan program reboisasi dan penghijauan 
pada wilayah-wilayah hutan dan lahan yang rusak di wilayah Sekaroh dan Pemongkong. Pada saat hutan di wilayah ini masih dalam keadaan baik tidak ditemukan adanya permasalahan yang berarti dalam praktek penggembalaan. Namun pada kondisi hutan yang telah rusak seperti sekarang ini, penggembalaan menjadi kendala utama bagi keberhasilan program reboisasi dan penghijauan hutan kembali. Penggembalaan merusak tanaman-tanaman muda yang baru ditanam dan menjadi penyebab penting kegagalan program reboisasi dan penghijauan di daerah ini. Permasalahan ini menjadi konflik yang cukup rumit dan masih belum ditemukan solusi yang tepat.

Berdasarkan hasil belajar bersama dengan masyarakat dapat disyarankan alternatif pemecahan yang mungkin dapat dilakukan adalah dengan menerapkan zona penggembalaan bergilir dengan mengalokasikan lokasi tertentu sebagai tempat penggembalaan yang dikelola secara terkendali. Pada lokasi-lokasi tempat dilakukan program penanaman dan penghijauan, penggembalaan tidak diperbolehkan sama sekali. Setelah tanaman cukup besar dan dipercayai tidak akan rusak karena penggembalaan, kemudian dapat disyarankan untuk diperbolehkan dijadikan tempat penggembalaan lagi. Cara seperti ini memang membutuhkan dana dan sumberdaya manusia yang cukup besar karena akan melibatkan masyarakat luas dalam pelaksanaannya.

\section{Permasalahan kepemilikan tanah}

Status kepemilikan tanah merupakan masalah pelik yang dihadapi masyarakat Desa Sekaroh dan Pemongkong Kabupaten Lombok Timur. Secara umum masyarakat di Desa Sekkaroh dan Pemongkong memiliki lahan yang cukup luas dengan rata-rata kepemilikan lebih dari dua hektar setiap kepala keluarga. Dari kepemilikan lahan yang ada secara umum masyarakat masih belum mampu mengerjakan seluruh lahan yang dimilikinya karena keterbatasan tenaga dan dana. Salah satu faktor penting dalam pengelolaan lahan yang mereka miliki adalah permasalahan gulma yang cukup berat yang tidak mudah diatasi dengan cara manual. Hal ini yang menyebabkan keterbatasan kemampuan mereka dalam mengelola lahan yang dimilikinya. Disamping itu biaya produksi (upah buruh tani, haraga pupuk, dan pestisida) yang cukup mahal sementara harga produk usaha tani yang dihasilkan relatif murah, menyebabkan petani enggan untuk mengusahakan seluruh lahan yang dimiliki untuk menanam berbagai jenis tanaman palawija.

Di wilayah Sekaroh dan Pemongkong terdapat lahan yang pemiliknya berasal dari luar. Lahan-lahan ini banyak yang tidak terurus dan ditumbuhi oleh semak belukar yang cukup rimbun sehingga sangat potensial sebagai tempat bersarangnya hama babi. Untuk mengatasi masalah hama babi, setiap musim kemarau masyarakat berusaha mengurangi jumlah populasinya dengan melakukan pemburuan babi secara masal/gotong royong. Untuk mengatasi masalah kepemilikan lahan, pemerintah daerah juga telah mengeluarkan berbagai aturan, namun dalam praktek beberapa pemilik lahan yang berdomilisi diluar Desa Sekaroh dan Pemongkong masih belum mentaati aturan yang ditetapkan oleh pemerintah Desa. Pada saat sekarang ini masyarakat Desa Sekaroh dan Pemongkong telah sepakat untuk memberlakukan peraturan adat yang lebih ketat bagi orang luar desa Sekaroh dan Pemongkong yang mau membeli tanah di Sekaroh dan Pemongkong. Pemilik lahan harus dengan sungguh sungguh memanfaatkannya dengan mengikuti awiqawiq yang disepekati oleh masyarakat Desa Pemongkong dan Sekaroh.

\section{B. Hasil Pengalaman Aksi Pembelajaran Nyata Di Desa Pemongkong dan Sekaroh}

\section{Terbentuknya kelompok masyarakat penghubung "Penjuluk"}

Untuk melakukan upaya pemberdayaan masyarakat dalam pelaksanaan action leaarning di Desa Pemongkong disadari bersama oleh masyarakat diperlukan kelompok kecil masyarakat penghubung (bahasa lokal penjuluk) yang memiliki kemampuan komunikasi yang cukup baik dan komitmen serta kesadaran yang kuat terhadap kelestarian 
sumberdaya alam dan lingungan. Pada periode awal pelaksanaan kegiatan, dengan fasilitasi Pokja Hutan dan Lahan masyarakat dapat menetapkan susunan keanggotaan kelompok kecil masyarakat tersebut. Hasil diskusi lebih lanjut memutuskan kelompok tersebut disebut dengan bahasa lokal "Penjuluk". Penjuluk dibentuk oleh masyarakat di Gubuk Erot (7 orang), Montong Bile (7 orang) dan Pemongkong (10 orang). Adapun penjuluk selama action learning di Desa Pemongkong adalah: (1) sebagai penghubung antara Pokja dengan seluruh masyarakat, (2) sebagai motivator, stimulator dan dinamisator seluruh masyarakat dalam pengelolaan hutan dan lahan kritis.

\section{Terbentuknya kelompok simpan pinjam}

Kelompok simpan pinjam dibentuk oleh masyarakat dengan fasilitasi Pokja. Modal awal kelompok berasal dari honor yang diberikan pada saat kegiatan Pokja. Keberadaan modal awal tersebut telah berhasil menstimulasi masyarakat untuk menabung di kelompok simpan pinjam sehingga modal kelompok mengalami pertambuhan yang cukup besar. Keinginan masyarakat untuk memajukan kelompok simpan pinjam disebabkan karena masyarakat menyadari pentingnya keberadaan kelompok tersebut. Pada saat datang beras murah/beras untuk orang miskin, kas yang ada pada kelompok simpan pinjam sangat sering dimanfatkan sebagai modal untuk membeli beras murah. Selanjutnya uang kelompok dikembalikan oleh masyarakat dalam tenggang waktu yang cukup lama. Disamping itu uang kelompok simpanpinjam juga sering dimanfaatkan untuk pembelian bibit tanaman palawija dan tanaman pepohonan.

\section{Terbentuknya kader penggerak untuk Pengelolaan hutan dan lahan kritis}

Setelah kegiatan Pokja Hutan dan Lahan Provinsi NTB berakhir pada bulan April 2004, Pokja masih terus berupaya untuk mendapingi masyarakat dalam pengelolaan hutan dan lahan kritis di Desa Pemongkong dan Sekaroh. Untuk menjamin keberlanjutan pelaksanaan pengelolaan hutan dan lahan kritis di Desa Pemongkong dan Sekaroh maka masyarakat dengan fasilitasi Pokja membentuk kader. Keanggotaan kader pada masing-masing gubuk dan tugas-tugas kader ditentukan sendiri oleh masyarakat. Tugas setiap kader yang dirumuskan masyarakat adalah: (1) sebagai penghubung antara Pokja dan Masyarakat, (2) sebagai motivator bagi masyarakat luas dalam pengelolaan hutan dan lahan kritis di Sekaroh dan Pemongkong, (3) mengkoordinir pemeliharaan ternak kambing agar tidak merusak hutan dan hasilnya sebagian dapat dimanfaatkan untuk pembelian bibit tanaman untuk menghijaukan lahan Desa Pemongkong.

\section{Meningkatkan Kesadaran Pengelolaan Hutan dan Lahan Kritis}

Mencermati fenomena konflik sumberdaya alam yang terus meluas dan berbagai permasalahan dalam pengelolaan hutan dan lahan kritis yang semakin pelik, upaya merajut hutan dan memugar lahan kritis bukanlah suatu pekerjaan yang mudah. Secara mendasar upaya untuk meningkatkan kesadaran dalam pengelolaan lingkungan yang benar merupakan tindakan yang mampu memicu langkah kongkrit berikutnya. Upaya ini tampaknya perlu ditingkatkan untuk membangun fondasi kebersamaan yang kuat untuk melakukan langkah-langkah lain yang perlu dilakukan.

Hasil pembelajaran dengan masyarakat di sekitar hutan Sekaroh dan Pemongkong selama dua tahun diperoleh hasil sebagai berikut. Upaya peningkatan kesadaran melalui pertemuan dan temu lapangan menunjukkan bahwa penanaman kesadaran akan pengelolaan lingkungan lebih awal sangatlah penting dan dapat menumbuhkan kesadaran pentingnya pengelolaan hutan dan lahan kritis secara baik. Belajar sambil bekerja untuk mencintai pohon dengan menanam tanaman buah dan tanaman pohon di halaman merupakan langkah awal yang baik untuk menumbuhkan kesadaran betapa pentingnya menanam pohon di ladang dan di kebun bahkan mungkin kesadaran untuk memelihara hutan negara.

Kepentingan pribadi mengawali timbulnya kesadaran menanam pohon pada pekarangan dan ladang pribadi. Namun dengan waktu kemudian muncul kesadaran kolektif bagaimana memikirkan untuk menanam pohon 
di hutan milik negara. Kesadaran ini muncul manakala masyarakat memahami pentingnya fungsi hutan, dan memulai memugar lahan sendiri yang akhirnya berlanjut dengan langkah dan upaya untuk memugar lahan milik negara.

Meningkatnya kesadaran kolektif masyarakat tentu harus diikuti dengan peningkatan kinerja institusi pemerintah dan institusi terkait lainnya. Berbagai cerita dari pengalaman masyarakat Sekaroh dan Pemongkong membuktikan lemahnya kinerja institusi pemerintah selama ini telah menjadi faktor penting penyebab penting kegagalan program-program pengelolaan hutan dan lahan kritis di wilayah ini.

\section{Masyarakat Montong Bile yang terampil memelihara kambing}

Dusun Montong Bile Desa Pemongkong terletak kira-kira $1 \mathrm{~km}$ di sebelah timur Dusun Pemongkong. Dusun ini memiliki 36 kepala keluarga. Hasil pembelajaran bersama masyarakat telah meningkatkan kesadaran mereka betapa pentingnya menanam pohon dan memelihara kebersihan lingkungan. Ketrampilan mereka dalam memelihara kambing selayaknya dijadikan modal dasar dalam penguatan kelembagaan mereka dalam berbagai aspek pengelolaan sumberdaya alam dan lingkungan. Sehingga peningkatan kemampuan mereka dalam berternak kambing haruslah diiringi dengan kemampuan mereka menjaga kebersihan lingkungan termasuk kemampuannya dalam mengelola kandang kambing yang bersih.

Berawal dari kegiatan berternak kambing dan berladang yang baik inilah tampaknya memungkinkan masyarakat Montong Bila untuk meningkatkan kelembagaannya secara kolektif. Kondisi biofisik yang ada dapat mendukung pengembangan kearah ini, utamanya tersedianya pakan yang memadai. Pembelajaran selama ini telah mampu meningkatkan kesadaran mereka untuk menanam pohon di pekarangannya sendiri. Bahkan sebagian masyarakat mulai membeli bibit-bibit pohon untuk ditanaman di pekarangannya sendiri dan di ladangladangnya. Kombinasi usaha tani terpadu ternak kambing dan pohon buah-buahan, serta pertanian tanaman pangan tampaknya dapat membuat mereka lebih berdaya dan mampu mengembangkan berbagai aktivitas kelembagaan untuk mengelola hutan dan lahan kritis di wilayahnya.

Hasil pemantaun di lapangan menunjukkan bahwa selama proses pembelajaran selama dua tahun ini, kesadaran dan kebanggaan masyarakat Dusun Montong Bile dalam menanam pohon dan mencoba untuk merawat dan melindungi pohon-pohon yang telah ada meningkat pesat. Jika kesadaran semacam ini terus dipupuk dan peningkatan kemampuan mereka terus ditambah melalui berbagai upaya, sangatlah mungkin keterlibatan mereka dalam pengelolaan hutan dan lahan kritis di wilayahnya akan terus meningkat pula.

6. Masyarakat Erot yang terampil dalam berkebun srikaya dan menanam bakau

Berbeda dengan Masyarakat Montong Bile, Masyarakat Erot yang terletak $1 \mathrm{~km}$ dari Montong Bile mempunyai ketrampilan yang baik dalam berkebun dan menanam bakau. Srikaya merupakan komoditas yang sangat digemari oleh masyarakat. Beberapa kader konservasi terbaik merupakan warga Erot dan telah menjadi kader konservasi unggulan untuk propinsi NTB. Beberapa kader telah berhasil dengan baik mengembangkan alley cropping untuk tanaman srikaya dan tanaman pohon seperti mahoni dan sengon.

Namun karena hasil sengon yang sebelumnya dijanjikan dapat dijual dengan harga yang menarik (setelah umur 5 - 7 tahun) belum dapat dinikmati, maka masyarakat mulai menebang pohon sengon tersebut dan mengganti dengan tanaman lain yang lebih memiliki nilai ekonomi yang baik. Disamping itu, masyarakat Erot yang di bombing Tokoh Agama TGH Sibawai telah mampu mengembangkan hutan bakau di sepanjang pesisir Erot sepanjang lebih $6 \mathrm{~km}$, yang sekarang menjadi hutan bakau yang sangat produktif. Keberhasilan dalam perbaikan ekosistim bakau yang telah dilakukan selama bertahun-bahun telah membuahkan hasilnya.

Sebelum hutan bakau berhasil dikembangkan, masyarakat Erot merasa sulit mencari kepiting dan berbagai hasil kerang- 
kerangan. Sekarang ini lokasi hutan bakau yang telah berhasil dikembangkan tersebut menjadi tempat yang sangat ramai untuk mencari berbagai hasil laut. Peningkatan penghasilan dari menangkap kepiting, kerang dan hasil laut lainnya pada sore hari yang dilakukan oleh ibu-ibu menghasilkan masukan yang tinggi untuk warga Erot. Yang tidak kalah penting adalah terpenuhinya protein hewani dari hasil laut yang diharapkan dapat meningkatkan kualitas SDM masyarakat Erot dan sekitarnya.

Walaupun beberapa kader konservasi terbaik ada di dusun ini, namun praktek konservasi lahan yang telah mereka kerjakan di ladang dan kebun mereka ternyata masih belum mampu menggerakkan sebagian besar warga Erot untuk menirunya. Dari hasil belajar bersama yang diperoleh dengan masyarakat ternyata diketahui bahwa ketidak mampuan mereka mengikuti jejak kader-kader konservasinya adalah karena ketidak berdayaan mereka secara ekonomi melakukan hal tersebut. Bimbingan, pendampingan, dan stimulasi yang diberikan pada mereka selama belajar bersama dapat meningkatkan kesadaran mereka dan merangsang mereka untuk melakukan penanaman pohon di pekarangan dan ladang mereka.

Selanjutnya, peningkatan kesadaran mereka dalam kelembagaan dengan dibentuknya kelompok simpan pinjam bersama dan berbagai upaya untuk mengatasi ketidak berdayaan mereka karena kurang modal, sedikit- demi sedikit mulai dapat teratasi. Stimulasi pemberian bibit buahbuahan dan pohon yang mereka inginkan dapat menumbuh kembangkan kesadaran akan arti penting mengelola pekarangan dan ladang. Stimulasi ini telah dapat meningkatkan kesadaran mereka yang luar biasa untuk menanam. Sekarang ini, baik secara kelompok atau sendiri-sendiri, mereka secara aktif terus berupaya untuk melakukan pengadaan bibit dan melakukan penanaman baik di pekarangan maupun ladang.

\section{Kesimpulan}

Kondisi hutan dan lahan di Propinsi Nusa Tenggara Barat (NTB) kini banyak yang rusak dan terdegradasi cukup parah. Di Desa Sekaroh dan Pemongkong Kabupaten Lombok Timur, kawasan hutan mengalami nasib yang sama: penebangan hutan, pembukaan lahan, dan penggunaan lahan hutan untuk pertanian telah menyebabkan terjadinya kerusakan hutan yang sangat masif.

Berbagai upaya telah dilakukan untuk mengembalikan fungsi hutan dengan berbagai keanekaragaman hayatinya. Pemerintah melalui berbagai instansi yang terkait telah melakukan berbagai program pemulihan, akan tetapi belum menunjukkan hasil yang diharapkan. Perbaikan hutan tak kunjung datang dan lahan kritis semakin luas jumlahnya. Tampaknya hambatan utama dalam pengelolaan hutan dan lahan kritis di Desa Sekaroh dan Pemongkong terletak pada permasalahan sosial budaya masyarakat.

Masyarakat Desa Sekaroh dan Pemongkong yang merupakan masyarakat pendatang (migran) dari berbagai daerah di Pulau Lombok dan daerah lainnya memiliki ciri yang pluralistis baik dari latar belakang sosial ekonomi maupun sosial budaya sehingga berdampak pada beragamnya pandangan dan perilaku masyarakat dalam menyikapi hutan dan lahan kritis. Di samping itu kondisi sosial ekonomi masyarakat yang tergolong relatif rendah telah memacu kerusakan hutan dan lahan kritis.

Pokja Hutan dan Lahan telah mencoba untuk turut berpartisipasi dan berjuang mengatasi permasalahan hutan dan lahan kritis di Desa Sekaroh dan Pemongkong dengan mengemas paradigma pembangunan yang bersendikan potensi lokal baik sumber daya alam maupun sumberdaya manusia dengan menekankan pada pembelajaran masyarakat (action learning) dan pemberdayaan masyarakat sebagai modal pembangunan. Paradigma modal sosial yang dibangun melalui pembelajaran nyata adalah modal sosial yang bersendikan "kebersamaan" yaitu dengan mencoba melihat peran-peran positif dari institusi-institusi sosial untuk diperankan dalam proses pembelajaran dalam pengelolaan hutan dan lahan kritis di Desa Sekaroh dan Pemongkong. Proses action learning yang telah dilakukan telah berhasil mendorong terjadinya kerjasama antar institusi seperti institusi keagamaan, adat, pemerintah setempat dan Pokja Hutan dan Lahan sebagai fasilitator dalam penyusunan rencana pengelolaan hutan dan lahan kritis untuk jangka pendek, menengah, dan jangka panjang. 


\section{Ucapan Terima Kasih}

Penulis mengucapkan terima kasih kepada BRISK Aus AID Peoject Australia khususnya Mr. John Wilson, Kate Dugan and Anne Cusson atas dukungan pendanaan untuk kegiatan ini selama dua tahun. 2002-2003. Ucapan terima kasih juga disampaikan kepada BAPELDA NTB yang memberikan kepercayaan pada Tim Pokja Hutan an Lahan Kritis untuk belajar bersama masyarakat Pemongkong dan Sekaroh Lombok Timur.

\section{Daftar Pustaka}

Konsorsium Pengembangan Dataran Tinggi Nusa Tenggara (2000). Teknik Participatory Rapid Appraisal. Bahan Pelatihan Dasar Metode PRA.

Oldeman, R.L., Irsal Las, and Muladi (1980). The Climatic Map of Kalimantan, Maluku, Irian Jaya, and Bali West Nusatenggara and East Nusatenggara. Contrib. No.60. Centr. Res. Inst. Agric. Bogor Indonesia.

Suwardji, Sukartono, Bambang HK, Ariabakti, A., P. Habibi dan M. Syaeful (2019). EcoMovement Berbasis Dakwah di Yayasan Darul Yatama Walmasakin Jerowaru Lombok Timur Melalui Media Teknologi dan Informatika.. Paper yang disampaikan pada Seminar Nasional PEPADU, Hotel Grand Legi 26 September 2019.

Suwardji, Sukartono, Bambang HK, Ariabakti, A., P. Habibi (2019). Kualitas Tanah Di Bawah Tegakan Agroforestri Tanaman Mahoni dan Sengon di Tanah Pasiran Lahan Sub Optimal Kering Pemongkong Lombok Timur Setelah 17 Tahun Penanaman. Paper yang disampaikan pada Seminar Nasional Saintek, di Hotel Golden Palace, 3 Oktober 2029.

Suryaningsun dan Suwardji (2009). Potensi Biomassa Tumbuhan Liar di Wilayah Sekaroh Lombok Timur Sebagai Sumber dan Penyedia Unsur Hara. Makalah yang disampaikan dalam Kongres Himpunan Ilmu Tanah Indonesia, UPN Yogyakarta Nov 2009.

Tarningsih H, Eko Handayanto dan Suwardji (2010). The Macroarthropod Diversities in Several Land System and Dryland Agroclimatic Zone in Lombok Island.
Prosiding National Seminar on Below Ground Biodiversity, Bandar Lampung, 2930 Juni 2010 pp 72-89.

Tejowulan Sri, Cusson, A. dan Suwardji (2004). Rehabilitasi Hutan dan Lahan Kritis: Belajar Dari Pengalaman Masyarakat. AusAID, Denpasar Bali 54 pages. 